\title{
Meningkatkan Mutu Belajar Siswa Kelas XI IPA 4 Melalui Bimbingan Terfokus pada SMA Negeri 4 Surakarta
}

\author{
Desi Kurniawati
}

SMA Negeri 4 Surakarta

desi.konselor21@gmail.com

\section{Article History}

accepted 01/11/2019

approved 11/11/2019

published 31/12/2019

\begin{abstract}
This study aims to improve the quality of learning of students of class XI IPA 4 in SMA Negeri 4 Surakarta through focused guidance in the even semester of the 2018/2019 academic year, and through focused guidance can improve the quality of learning of students of class XI IPA 4 in SMA Negeri 4 Surakarta in the even semester 2018/2019 school year. The research action was carried out in two cycles, each cycle consisting of planning, implementing, observing and reflecting. Data was collected using monitoring and evaluation instruments to determine the management and administration capabilities of the school principal. The results were analyzed using descriptive analysis. The results of the analysis showed that there was an increase in the quality of learning of students in class XI IPA 4 with the average score of action I, from initial conditions to cycle I of 45.15 to 62.23 and increased again in cycle II by ie from cycle I to cycle II of 14, 30 Improvements also occurred in focused guidance with a mean score of cycle I action, from initial conditions to cycle I of 64.48 and cycle II, ie from cycle I 72.65 to cycle II of 79.08. So it can be concluded that focused guidance on students of class XI IPA 4 in SMA Negeri 4 Surakarta can be improved through focused discussion.
\end{abstract}

Keywords: Quality, Learning, Focused Guidance

\begin{abstract}
Abstrak
Penelitian ini bertujuan untuk meningkatkan mutu belajar siswa kelas XI IPA 4 di SMA Negeri 4 Surakarta melalui bimbingan terfokus pada semester genap tahun pelajaran 2018/2019, dan melalui bimbingan terfokus dapat meningkatkan mutu belajar siswa kelas XI IPA 4 di SMA Negeri 4 Surakarta pada semester genap tahun pelajaran 2018/2019. Tindakan penelitian dilakukan dua siklus yang masing-masing siklus terdiri dari tahap perencanaan, pelaksanaan, pengamatan dan refleksi. Data dikumpulkan menggunakan instrumen monitoring dan evaluasi untuk mengetahui kemampuan manajemen dan administrasi kepala sekolah. Hasilnya dianalisis menggunakan analisis diskriptif. Hasil analisis menunjukkan bahwa terjadi peningkatan mutu belajar siswa kelas XI IPA 4 dengan skor rerata pada tindakan I yaitu dari kondisi awal ke siklus I sebesar 45,15menjadi 62,23 dan meningkat lagi pada siklus II sebesar yaitu dari siklus I ke siklus II sebesar 14,30. Peningkatan juga terjadi pada bimbingan terfocus dengan skor rerata tindakan siklus I yaitu dari kondisi awal ke siklus I sebesar 64,48 dan tindakan siklus II yaitu dari siklus I 72,65 ke siklus II sebesar 79,08. Maka dapat disimpulkan bahwa bimbingan terfocus pada siswa kelas XI IPA 4 di SMA Negeri 4 Surakarta dapat ditingkatkan melalui tindakan diskusi terfokus.
\end{abstract}

Kata kunci: Mutu, Belajar, Bimbingan Terfokus

Social, Humanities, and Education Studies (SHEs): Conference Series https://jurnal.uns.ac.id/shes

p-ISSN 2620-9284

e-ISSN 2620-9292 


\section{PENDAHULUAN}

Kegiatan belajar yang dilakukan oleh manusia itu akan berhasil jika dilatarbelakangi oleh suatu dorongan dalam diri manusia tersebut yang umumnya dikatakan sebagai motivasi. Ngalim Purwanto, (1999: 72) mengatakan bahwa motivasi adalah syarat mutlak untuk belajar. Hal ini disebabkan karena tanpa motivasi hasil belajar siswa tidak akan optimal dan stimulus belajar yang diberikan tidak akan berarti (Sriyono, (1992: 26). Berdasar data dokumentasi dari guru kelas XI IPA 4 SMA Negeri 4 Surakarta, hasil prestasi siswa nilainya masih perlu ditingkatkan, siswa yang mendapat nilai 65 ke atas lebih sedikit dibanding dengan siswa yang memperoleh nilai 65 kebawah. Hal ini menunjukan bahwa tingkat kualitas belajar siswa masih rendah, yang perlu untuk ditingkatkan.

Dalam hubungannya dengan kegiatan belajar, yang penting bagaimana menciptakan kondisi atau suatu proses yang mengarahkan siswa untuk melakukan aktivitas belajar. Dalam hal ini peran guru sangat penting, yaitu bagaimana guru melakukan usaha-usaha untuk dapat menumbuhkan dan memberikan motivasi agar siswa melakukan aktifitas belajar yang baik. Untuk dapat belajar dengan baik diperlukan proses dan motivasi yang baik pula, salah satunya dengan memberikan layanan bimbingan belajar.

Adanya bimbingan belajar diharapkan dapat menimbulkan motivasi belajar bagi siswa. Motivasi merupakan salah satu factor yang penting untuk mencapai keberhasilan siswa. Siswa yang termotiwasi akan mengarahkan dirinya pada suatau usaha untuk mencapai tujuan. Dalam hal ini Sardiman, AM (2001 : 73) menyatakan bahwa : Supervisi manajerial dengan teknik bimbingan terfokus yang dilakukan guru pengajar dan bimbingan karier merupakan salah satu upaya meningkatkan kualitas belajar siswa. Kegiatan bimbingan terfokus, guru pengajar dan bimbingan karier dapat secara langsung membina, mengarahkan, dan membimbing siswa dalam pembelajaran. Sehingga diharapkan guru dapat meningkatkan kualitas belajar siswa melalui proses pembimbingan terfocus. Bentuk pembinaan guru pengajar dan bimbingan karier yang sebelumnya belum menyeluruh dapat dilaksanakan melalui kegiatan bimbingan terfokus. Bimbingan kelompok terfokus (Focus Group Discussion/FGD (bimbingan focus)) merupakan suatu metode pengumpulan data yang lazim digunakan pada penelitian kualitatif sosial, tidak terkecuali pada penelitian kepenedidikan.

Berpangkal dari asumsi tersebut diatas, penulis memandang perlu diadakan penelitian tindakan yang berorientasi pada peningkatan disiplin siswa terhadap tata tertib sekolah dengan mengambil judul Meningkatkan Mutu Belajar Siswa Kelas Xi Ipa 4 Melalui Bimbingan Terfokus Pada Sma Negeri 4 Surakartasemester Genap Tahun Pelajaran 2018/2019.

Penelitian tindakan kelas ini ini dapat di rumuskan permasalahan sebagai berikut: "Apakah melalui bimbingan terfokus dapat meningkatkan mutu belajar siswa kelas XI IPA 4 di SMA Negeri 4 Surakarta pada semester genap tahun pelajaran 2018/2019?"

\section{Lokasi Penelitian}

\section{METODE}

Lokasi penelitian dilakukan kelas XI IPA 4 di SMA Negeri 4 Surakarta, dengan pertimbangan proses penelitian lebih mudah dalam mendapatkan data. Selain itu sekolah tersebut juga mengijinkan digunakan untuk kegiatan penelitian.

\section{Waktu Penelitian}

Waktu penelitian ini dilakukan mulai bulan April 2019 sampai dengan awal Juli 2019 kurang lebih selama empat bulan. Tahapan penelitian ini terdiri dari dua siklus.

\section{Subjek Penelitian dan Variabel Penelitian}

a. Subjek Penelitian 
Populasi penelitian ini diambil dari siswa kelas XI IPA 4 SMA Negeri 4 Surakarta, berjumlah 32 siswa. Oleh karena itu, penelitian ini adalah penelitian kasus, maka populasinya ditentukan scara random/acak. menurut Arikunto (2003: 93) sekedar ancer-ancer maka apabila subjeknya atau populasinya sedikit peneliti dapat menentukan sampel penelitiannya berdasar kasus yang diteliti. Responden untuk penelitian diambil sebanyak 8 orang siswa, yang rangkingnya rendah untuk dijadikan subjek penelitian.

b. Variabel Penelitian

Sebagai variabel terikat dalam penelitian ini adalah peningkatan mutu belajar siswa, sedangkan variabel bebasnya adalah bimbingan terfocus kepada siswa peserta penelitian tindakan.

\section{Pengumpulan Data}

a. Observasi

Data observasi adalah sikap dan perilakau siswa kelas XI IPA 4 terhadapupaya peningkatan mutu belajar siswa dan kegiatan bimbingan terfocus terhadap topik masalah yang dihadapi siswa kelas XI IPA 4 pada SMA Negeri 4 Surakarta yang dicatat sebanyak tiga kali untuk masing-masing siklus penelitian tindakan kelas ini.

b. Data Dokumentasi

Data dokumentasi diperoleh dengan langkah-langkah sebagai berikut:

1). Peneliti mencatat hal peningkatan mutu belajar siswa dari hasil bimbingan terfocus selama penelitian tindakan kelas ini berlangsung pada setiap siklus penelitian tindakan kelas.

2). Peneliti menganalisis dokumentasi hasil peningkatan mutu belajar siswa melalui bimbingan terfocus, kedua siklus itu untuk menguji hipotesis dan

\section{Analisis Data} mengambil hasil kesimpulan penelitian tindakan kelas.

\section{a. Siklus I}

Pada tahapan ini maka peneliti melakukan pengolahan data yang menunjukkan:

1). Data kualitatif kemampuan siswa peserta dalam rangka ikuti perlakuan bimbingan terfocus kelompok belajar

2). Data Kuantitatif tentang mutu belajar siswa kelas XI IPA 4 SMA Negeri 4 Surakarta melalui bimbingan terfocus, kemudian peneliti melakukan tindak b. Siklus II lanjut yaitu siklus II.

Pada tahap ini peneliti melakukan pengolahan data yang diperoleh dari siklus tindakan untuk menunjukkan:

1). Data observasi peningkatan mutu belajar siswa melalui bimbingan terfocus di SMA 4 Surakarta.

2). Data dokumentasi untuk hasil kinerja.

\section{Indikator Kinerja}

Kriteria bimbingan konseling yakni dapat/tidaknya siswa menunjukkan suatu peningkatan disiplinnya terhadap tata tertib dan peraturan sekolah, dengan indikator kualitatif mencapai $80 \%$, dan dikomparasikan dengan permendiknas Nomor 41 Tahun 2007 tentang Standar Proses untuk Satuan Pendidikan Dasar dan Menengah. Apabila hasilnya telah mencapai $80 \%$ ke atas, maka hipotesis diterima, bila tidak mencapai 80 $\%$ hipotesis ditolak..

\section{A. Hasil}

\section{HASIL DAN PEMBAHASAN}

\section{Deskripsi Kondisi Awal}

Manajemen pembelajaran dalam merumuskan kurikulum, belum semua guru memahami, dokumen pengawasan guru masih minimal, pembinaan personal juga 
kurang, dan administrasi guru belum lengkap. Sehingga apabila dirata-rata keterlaksanaan pengelolaan kelas oleh guru di SMA Negeri 4 Surakarta dalam kategori masih perlu peningkatan.

\section{Tindakan Siklus I}

Berdasar uraian kondisi awal diatas, siswa perlu mendapatkan bimbingan terfocus dalam kaitannya dengan meningkatkan mutu belajar siswa. Supaya siswa memiliki kemampuan meningkatkan mutu belajar perlu adanya tindakan. Cara melakukan tindakan dengan supervisi manajerial teknik bimbingan terfokus dengan melakukan dua tindakan. Tindakan pertama (siklus I) dan tindakan kedua (siklus II), dimana peneliti berusaha untuk melakukan pembinaan secara klasikal atau kelompok (siklus I) yaitu memilih subjek penelitian tindakan yakni siswa kelas tertentu di SMA Negeri 4 Surakarta untuk memperoleh pembinaan tentang pembelajaran yang benar sesuai dengan pedoman. Hasil refleksi siklus I dijadikan dasar untuk membuat perencaan tindakan pada siklus II yakni bimbingan terfocus. Rencana tindakan pada siklus II hari Selasa tanggal 18 Juli 2019, adalah melakukan diskusi terfokus secara individual siswa peserta dilaksanakan secara individu.

a) Refleksi Pada Siklus I peningkatan mutu belajar siswa.

Hasil tindakan menunjukan semua aspek peningkatan mutu belajar siswa meningkat dengan selisih antara 07.57 sampai 30,00. Aspek Sikap terhadap materi ajar meningkat dengan selisih 12.85 , aspek pemahaman materi ajar meningkat dengan selisih 30,00, aspek penguasaan materi ajar meningkat dengan selisih 07,57, aspek perilaku koqnitif dan afektif siswa meningkat dengan selisih 18,57, dan aspek perilaku psikomotorik meningkat dengan selisih 16,42.

Komponen yang mengalami peningkatan paling besar adalah Pemahaman materi ajar dengan selisih 30.00 dan terendah pada aspek Penguasaan materi ajar dengan selisih 07.57. Peningkatan juga dapat diketahui dari skor rata-rata dari 45,07 pada kondisi awal, menjadi 62,23 pada siklus I, sehingga memiliki selisih 17,16. Dengan skor rata-rata bertambah besar menunjukkan telah terjadi peningkatan mutu belajar siswa. Aspek skor rata-rata di bawah 60, yaitu aspek penguasaan materi ajar.

b) Refleksi Pada Siklus I bimbingan terfocus pada siswa.

Hasil refleksi hampir semua indikator bimbingan Terfocus kelas XI IPA 4 SMA Negeri 4 Surakarta mengalami peningkatan dengan selisih antara 0,78 sampai dengan 13,54. Indikator masalah/topik harus muncul dari siswa meningkat dengan selisih 06,25 , indikator pemahaman terhadap masalah kuat meningkat dengan selisih 02,09 , indikator taraf pertumbuhan profesi meningkat dengan selisih hanya 0,78 , indikator kerja kelompok untuk kajian ulang meningkat dengan selisih 09,37, indikator pertimbangan personal meningkat dengan selisih 13,54, indikator mengelola ULK meningkat dengan selisih 13,02, dan indikator program pengawasan meningkat dengan selisih 05,20.

Indikator yang mengalami peningkatan paling besar adalah mengelola ketatausahaan dengan 13,54 dan terendah pada indikator pengembangan kurikulum dengan 0,78. Peningkatan juga dapat diketahui dari skor rata-rata dari 65,48 pada kondisi awal menjadi 72,65 pada siklus I, sehingga memiliki selisih 07,17 . Skor ratarata bertambah besar menunjukkan telah terjadi peningkatan kemampuan administrasi guru.

\section{Deskripsi Hasil Siklus II}

a. Rencana Tindakan Siklus II

Hasil refleksi siklus I dijadikan dasar membuat perencaan tindakan pada siklus II pada hari Selasa tanggal 18 Juli 2019, dengan melakukan diskusi terfokus secara individual siswa peserta penelitian tindakan ini mewakili kelas IPA 4 SMA Negeri 4 Surakarta. Peningkatan mutu belajar siswa dilaksanakan secara individu, diberi 
pembinaan cara : (a) menyikapi materi ajar, (b) Pemahaman materi ajar; (c) Penguasaan materi ajar; (d) Perilaku koqnitif dan afektif; (e) Perilaku psikomotorik.

Diskusi difokuskan pada aspek/materi yang masih lemah hasil siklus I. Aspek yang menjadi fokus tindakan pada : (a) kemampuan siswa untuk memunculkan masalah atau topik; (b) mendukung pertumbuhan profesi belajar sehingga (c) memiliki kemampuan observasi masalah dan (d) kemampuan menulis dan penyajian masalah.

b. Pelaksanaan tindakan Siklus II

Tahap ini penelitian tindakan kepada guru sesuai dengan jadwal yang telah direncanakan yakni hari Jumat tanggal 12 Juli 2019. Diskusi terfokus dapat dilaksanakan dengan lancar dengan fokus kepada aspek yang lemah pada siklus I, yaitu tentang : (a) kemampuan siswa untuk memunculkan masalah atau topik; (b) mendukung pertumbuhan profesi belajar sehingga (c) memiliki kemampuan observasi masalah dan (d) kemampuan menulis dan penyajian masalah. Setelah melakukan tindakan terhadap masing-masing guru, maka dilanjutkan dengan pemantauan untuk mengetahui perkembangan meningkatkan mutu belajar siswa setelah tindakan.

1) Refleksi Peningkatan mutu belajar siswa Pada Siklus II

Refleksi pada mutu belajar siswa mengalami peningkatan dengan selisih antara 6,54 sampai dengan 49.04. Aspek sikap terhadap materi ajar meningkat dengan selisih 32,59 , aspek pemahaman terhadap materi ajar meningkat dengan selisih 49.04, aspek penguasaan materi ajar meningkat dengan selisih 19,39, aspek perilaku koqnitif siswa meningkat dengan selisih 6,54, dan aspek perilaku psikomotorik siswa meningkat dengan selisih 06,80.

Komponen yang mengalami peningkatan paling besar adalah pemahaman terhadap materi ajar $(49,04)$, sedangkan yang terendah pada aspek perilaku koqnitif siswa $(06,54)$. Peningkatan juga dapat diketahui dari skor rata-rata dari 62,23 pada siklus I menjadi 76,53 pada siklus II, sehingga memiliki selisih 14,30. Bertambahnya skor rata-rata menunjukkan terjadi peningkatan mutu belajar siswa. Pembinaan guru dalam kegiatan bimbingan terfocus telah memberi pengaruh hasil peningkatan mutu belajar siswa. Selisih antar siklus I dengan siklus II tidak merata hal ini menjadi perhatian pada kualitas belajar siswa.

2) Refleksi bimbingan terfocus siswa Pada Siklus II

Refleksi untuk semua indikator bimbingan terfocus siswa dan guru mengalami peningkatan dengan selisih antara 1,56 sampai dengan 14,17. Indikator topik masalah muncul dari siswa meningkat dengan selisih 10,94, indikator pemahaman masalah memadai atau kuat meningkat dengan selisih 05,20, indikator taraf pertumbuhan tentang profesi yang meningkat dengan selisih 10,16, indikator penyelidikan atau observasi masalah yang meningkat dengan selisih 07,82 , indikator bimbingan kelompok untuk kajian ulang meningkat dengan selisih 14,17, indikator pertimbangan personal meningkat dengan selisih 1,56, dan indikator kemampuan menulis masalah meningkat dengan selisih 6,25.

Indikator bimbingan terfocus yang telah mengalami peningkatan paling besar adalah aspek topik masalah muncul dari siswa dan terendah Nampak pada aspek Pertimbangan personal. Maka pada Peningkatan juga dapat diketahui dari skor ratarata dari 72,65 pada siklus I menjadi 78,79 pada siklus II, sehingga memiliki selisih 6,14 . Dengan skor rata-rata bertambah besar menunjukkan telah terjadi peningkatan mutu belajar siswa dengan bimbingan terfocus. Besar peningkatan masing-masing indikator berbeda-beda dan Topik masalah yang muncul dari siswa memiliki selisih paling tinggi. Sudah tidak ada indikator bimbingan terfocus yang memiliki skor rata-rata di bawah 60.

\section{B. Pembahasan}

Diterimanya hipotesis dalam penelitian ini dikarenakan dengan penerapan bimbingan terfocus bagi siswa kelas XI IPA 2 SMA Negeri 4 Surakarta, setiap siswa 
peserta mendapatkan kesempatan untuk meningkat mutu belajarnya karena menjadi lebih mudah memahami dan mendalami pentingnya meningkat mutu belajarnya sesuai dengan Undang-undang 20 Tahun 2003 dengan kegiatan:

1. Kemampuan siswa untuk munculkan masalah atau topik;

2. Mendukung adanya pertumbuhan potensi belajar;

3. Memiliki kemampuan kajian dan observasi masalah,

4. Kemampuan menulis dan penyajian masalah.

Kondisi ini kelak akan memberikan dukungan terhadap upaya para guru bimbingan dan konseling di SMA Negeri 4 Surakarta meningkatkan mutu belajar siswanya melalui bimbingan terfocus.

Uraian hasil penelitian tindakan di atas disimpulkan bahwa: (1) diskusi terfokus dapat meningkatkan skor mutu belajar siswa kelas XI IPA 4 di SMA Negeri 4 Surakarta dari kondisi awal ke siklus I sebesar 17,08 dan peningkatan dari siklus I ke siklus II sebesar 14,30; dan (2) diskusi terfokus dapat meningkatkan skor mutu belajar siswa dari kondisi awal ke siklus I sebesar 7,17 dan peningkatan dari siklus I ke siklus II sebesar 6,43.

Berdasarkan hasil penelitian tersebut di atas, peningkatan mutu belajar siswa kelas XI IPA 4 terjadi pada semua siklus di SMA Negeri 4 Surakarta, maka penelitian tidak dilanjutkan ke siklus III karena sudah menunjukkan hasil yang signifikan.

\section{SIMPULAN}

Berdasarkan hasil penelitian tindakan kelas di atas, peneliti membuat simpulan sebagai berikut:

a) Peningkatan mutu belajar siswa kelas XI IPA 4 di SMA Negeri 4 Surakarta dari kondisi awal sampai siklus II hampir terjadi disemua aspek. Peningkatan juga terjadi pada skor rerata kondisi awal semula sebesar 45,15 menjadi 62,23 pada siklus I dan meningkat lagi menjadi 76,53 pada siklus II. Hal ini berarti pada tindakan siklus I terjadi peningkatan skor 17,08 dan pada tindakan pada siklus II mengalami peningkatan skor 14.30. Skor terendah kondisi awal sebesar 31,43 menjadi 46,86 pada siklus I dan meningkat lagi menjadi 66,25 pada siklus II. Selanjutnya pada skor tertinggi di kondisi awal sebesar 64,29 menjadi 77,14 pada siklus I dan menjadi sebesar 96,88 pada siklus II.

b) Bimbingan terfocus siswa kelas XI IPA 4 di SMA Negeri 4 Surakarta dari kondisi awal sampai siklus II hampir terjadi disemua indikator kinerja. Peningkatan pada skor rerata, yaitu kondisi awal semula sebesar 65,48 menjadi 72,65 pada siklus I dan meningkat lagi menjadi 79,08 pada siklus II. Hal ini berarti pada tindakan siklus I terjadi peningkatan skor 7,17 dan pada tindakan pada siklus II mengalami peningkatan skor 6,43.

Skor terendah kondisi awal sebesar 59,38 menjadi 64,58 pada siklus I dan meningkat lagi menjadi 85,94 pada siklus II. Selanjutnya pada skor tertinggi di kondisi awal sebesar 76,04 menjadi 78,13 pada siklus I dan menjadi sebesar 91,67 siklus II. Semua indikator bimbingan terfocus siswa dengan guru mulai kondisi awal sampai siklus II mengalami peningkatan tidak sama. Pada tindakan siklus I peningkatan paling tinggi pada indikator Pemahaman terhadap masalah kuat $(78,13)$, sedangkan tindakan siklus II pada indikator Taraf pertumbuhan profesi $(85,94)$.

\section{DAFTAR PUSTAKA}

Ngalim Purwanto, (2004). Psikologi Pendidikan. Bandung Remaja Rosda Karya.

Robert M. Gagne dalam Hamzah B. Uno, (2008). Teori Motivasi dan Pengukurannya: Analisis di bidang pendidikan. Bumi Aksara: Jakarta.

Sahertian. (2008). Konsep dan Teknik Supervisi Pendidikan: Dalam Rangka Pengembangan Sumber Daya Manusia. Jakarta: Rineka Cipta PT. 
4th National Seminar on Guidance and Counseling (SNBK 2019) and Workshop on

Pedagogical Theory and Practice (WTPP 2019)

SHEs: Conference Series 2 (2) (2019) 8 - 14

Sallis, Edward. (2012). Total Quality Management in Education, Terjemahan: Manajemen Mutu Terpadu Pendidikan. Yogyakarta: IRCiSoD.

Sardiman, (2001). Interaksi dan Motivasi Belajar Mengajar. Jakarta: Radjawali.

Soedijarto, (1993). Pendekatan Strategi Belajar Mengajar. Sinar Baru. Jakarta.

Sriyanto. (1992). Belajar dan Pembelajaran. Jakarta: Rineka Cipta

Sudjana, Nana. (2011). Supervisi Pendidikan Konsep Dan Aplikasinya. BekasiIndonesia: Binamitra Publishing.

Thomas L. Good \& Jere E. Brophy, (1990). Educational Psychologhy. New York: Longman.

Tim Pengembang IImu Pendidikan FIP-UPI. (2007). Ilmu \& Aplikasi Pendidikan: Bagian 1 Ilmu Pendidikan Teoritis. FIP-UPI. Imperial Bhakti Utama PT.

Usman, Husaini. (2001). Manajemen: Teori, Praktik, dan Riset Pendidikan. Jakarta: Bumi Aksara PT.

Wragg. Herzberg, Federick, (1968), One More Time - How Do You Motivate Employee , Harvard Business Review. (http://www. wikipedia.com) 